\title{
Clinical Manifestation and Management of Terrestrial Animal Bites
}

\author{
Emma Hidayati Sasmito, Sawitri \\ Department of Dermatology and Venereology, Faculty of Medicine, Universitas Airlangga/Dr. \\ Soetomo General Academic Hospital, Surabaya, Indonesia
}

\begin{abstract}
Background: Terrestrial animal bites wounds are injuries caused by terrestrial animals' mouths and teeth. Aerobic and nonaerobic bacteria cause $30-60 \%$ of the secondary bacterial infections due to animal bites. Rabies is an infectious disease and it is the most dangerous viral infection caused by animal bites. Also, venomous animal bites can be fatal and cause death if not treated well. Purpose: To identify the clinical manifestation, first aid, and management of terrestrial animal bites to reduce morbidity and mortality. Review: Wounds and crush injuries caused by animal bites are prone to infection. Aerobic bacteria, such as Pasteurella multocida, Staphylococcus spp. (including methicillin-resistant Staphylococcus aureus (MRSA)), Capnocytophaga canimorsus, and Bartonella henselae, and anaerobic bacteria, such as Porphyromonas spp. are commonly found pathogens in animal bite wounds. Rabies, the most dangerous viral infection, occurs in wounds infected by the rabies virus. The virus enters the nerve tissue, multiplies, and spreads to the central nervous system. This can cause disability, and it is life-threatening. In snakebites, management of basic life support, transportation to the hospital, clinical assessment, and immediate resuscitation are the most important procedures. Conclusion: Animal bite wounds are injuries caused by animals' mouths and teeth. Dogs, cats, and snakes are terrestrial animals that most likely attack humans. Proper diagnosis, first aid, and comprehensive management are needed to reduce morbidity and mortality.
\end{abstract}

Keywords: Terrestrial animal bites, wound, infectious disease.

Correspondence: Sawitri, Department/Functional Medical Staff of Dermatology and Venereology, Faculty of Medicine, Universitas Airlangga/Dr. Soetomo General Academic Teaching Hospital, J1. Mayjend Prof. Dr. Moestopo No. 6-8 Surabaya 60131, Indonesia. Telepon: 0818309859, email: sawitri.rh@gmail.com.

\section{BACKGROUND}

Terrestrial animal bites wounds are injuries caused by terrestrial animals' mouths and teeth. ${ }^{1}$ The impact of animal bites depends on the type of animal biting, animal health status, victim's health status, and ease of access to health care facilities. ${ }^{2}$

WHO estimates that a million people in the United States got bitten by animals each year. Animal bites are responsible for $1 \%$ of emergency hospital visits. In the United States, dogs and cats are responsible for $60-80 \%$ and $20-30 \%$ of animal bites cases, respectively. Furthermore, $10-15 \%$ of animal bites cases are caused by snakes, while other animal bites, such as rabbits, hamsters, rats, and monkeys, contribute to $1-2 \%$ of animal bites. ${ }^{1}$ In Indonesia, the total number of rabies cases is 16,258 in $2013 .{ }^{3}$ WHO estimates 421,000 snakebite cases in total, with 20,000 death occurred in South Asia. ${ }^{4}$

The spectrum of animal bite wounds is extensive. Bite-on-hand wounds, puncture wounds, and crush injury are prone to infection. Aerobic and anaerobic bacteria cause thirty to sixty percent of the secondary bacterial infections in animal bites. ${ }^{5}$ The complications of secondary bacterial infections include osteomyelitis, amputation, septic arthritis, septic shock, and death. ${ }^{6}$ Rhabdovirus causes rabies, which is an infectious disease and the most dangerous viral infection caused by the animal bite. ${ }^{7}$

Snakebites can be fatal and lead to death. It is important to raise awareness of challenges in managing snakebites, particularly in rural areas where health facilities are not easily accessible. The population has high morbidity and mortality due to poor access to health services and the scarcity of antivenom, which is the only specific treatment. ${ }^{8}$ Improper management, diagnosis, and treatment of snakebites may result in disability and life-threatening situation. ${ }^{9}$

This literature review will discuss the clinical manifestations and treatment of terrestrial animal bites included dog, cat, and snakebites. Many complications can be prevented with proper diagnosis and handling to reduce morbidity and mortality.

\section{REVIEW}

Terrestrial animal bite usually happens when a person directly interacts with animals. It is also reported in cases where veterinarians are treating animals. A terrestrial animal bite is an injury caused by 
the mouth and teeth of terrestrial animals. ${ }^{1}$ Many of the terrestrial animal bites involve the upper extremities, especially the hand area. The impact of terrestrial animal bites depends on the type of animal biting, animal health status, victim's health status, and health facilities accessibility. ${ }^{2}$

Animal bites should be evaluated and treated carefully by considering bite events, animal types, bite locations, and local geographic data. Hand injuries, puncture wounds, and crush injury are at risk for secondary infectious wounds. Before taking the specimen for culture examination and gram staining, the infected bite wound should be cleaned. ${ }^{5,10}$ The animal bite wounds are classified based on severity (Table 1). ${ }^{1}$

Most animal bites occur in the hands, followed by arm, leg, and face (Table 2). Certain bite locations have a higher risk for infection. Bite in the hand area has an $18-36 \%$ risk of infection. ${ }^{1}$

Table 1. The severity of animal bite wounds. ${ }^{1}$

\begin{tabular}{|c|c|c|}
\hline Grade I & Grade II & Grade III \\
\hline $\begin{array}{l}-\quad \text { Superficial skin } \\
\text { infection }\end{array}$ & $\begin{array}{l}\text { - Wounds extend from skin to fascia, } \\
\text { muscles, or cartilage. }\end{array}$ & $\begin{array}{l}\text { - Wound with tissue necrosis } \\
\text { or tissue loss. }\end{array}$ \\
\hline - Skin tear & & \\
\hline - Scratch & & \\
\hline - Bite canal & & \\
\hline - Crushing injury & & \\
\hline
\end{tabular}

Table 2. Risk of infection based on bite location. ${ }^{11}$

\begin{tabular}{cc}
\hline Bite location & Risk of infection \\
\hline Hand & $18-36 \%$ \\
Arm & $17-20 \%$ \\
Leg & $7-15 \%$ \\
Face & $4-11 \%$ \\
\hline
\end{tabular}

Many dog bites involve the upper extremities, especially the hand area. Animal bites can cause bacterial and viral secondary infections. Pasteurella multocida 50-60\% are found in dogs' nasopharynx. Rabies, which is caused by Rhabdovirus, is the most dangerous viral infection caused by animal bites. In recent years, epidemiology has changed due to increased control of rabies in domestic animal populations. Currently, only $8 \%$ of rabies cases are caused by dogs and domestic animals. Post-bite prophylaxis treatment, which is almost $100 \%$ effective, can lower the number of rabies in humans. One century ago, there were 100 cases compared to the average of 1-4 cases annually in the United States today.,

Rabies viruses live in neural tissues of the biting site, multiplicate, and then spread to the central nervous system (Figure 1). The virus replicates in the grey matter and then spreads along the autonomic nerve to the salivary gland, adrenal gland, and heart. The incubation period of this viral infection depends on the bite location, ranging from 5 days to several years. ${ }^{2}$

The clinical manifestation starts with the prodromal period of 1-4 days, with high fever, dizziness, and malaise. Paresthesia at the location of inoculation occurs in $80 \%$ of patients. Then appear the subsequent symptoms such as agitation, hyperesthesia, dysphagia, excessive thirst, paralysis, and death. ${ }^{5}$ The most important step is to clean the wound immediately with a brush and soap to kill the viruses as much as possible. The wound should be well-rinsed and then rebrushed using detergent or $70 \%$ alcohol or iodine, which has rabicidal (killing rabies) effect. ${ }^{12}$

Aerobic and nonaerobic bacteria cause $30-60 \%$ of bacterial infections due to animal bites. Aerobic bacteria such as Pasteurella spp., Staphylococcus ssp. (including MRSA), Capnocytophaga canimorsus, and Bartonella henselae. Anaerobic bacteria such as Porphyromonas spp. are the common pathogens found in animal bite wounds (Table 3 ). ${ }^{1}$

Cat bite is the second frequent mammal bite after dog bite. Cat bite wounds pose almost two times in infection than dog bite, which is as much as $60-70 \%{ }^{2}$ Pasteurella multocida is a bacterium that usually presents in cat bite wounds, and it is the most common pathogen (70-90\%) found in cat nasopharynx. ${ }^{1}$

The risk of infection of animal bites is determined based on the wound nature, patient characteristics, and animal species. Cat bites have a higher risk of infection due to the taper and pointed cat teeth that cause deep wounds or punctures wound (Table 4). ${ }^{1}$

Pasteurella is a common organism found in infected cat bites. Pasteurella is the normal oral flora 
in $70 \%$ to $90 \%$ of healthy cats. It is a small, Gramnegative coccobacillus, which is difficult to be cultured. Clinical evidence has documented MRSA colonization in domestic animals, often implying direct acquisition from their human owners. Pasteurella infections are particularly aggressive, usually presenting within $12-48 \mathrm{~h}$ unless partially treated. ${ }^{13}$
Infected cat bites can contain a mix of different micro-organisms from the animal's oral cavity and or the patient's skin normal flora, including the species of Pasteurella, Streptococcus, Staphylococcus, Corynebacterium, Moraxella and Capnocytophaga, and anaerobic bacteria Porphyromonas spp. are the common pathogens found in animal bite wounds (Table 5). ${ }^{1,13}$

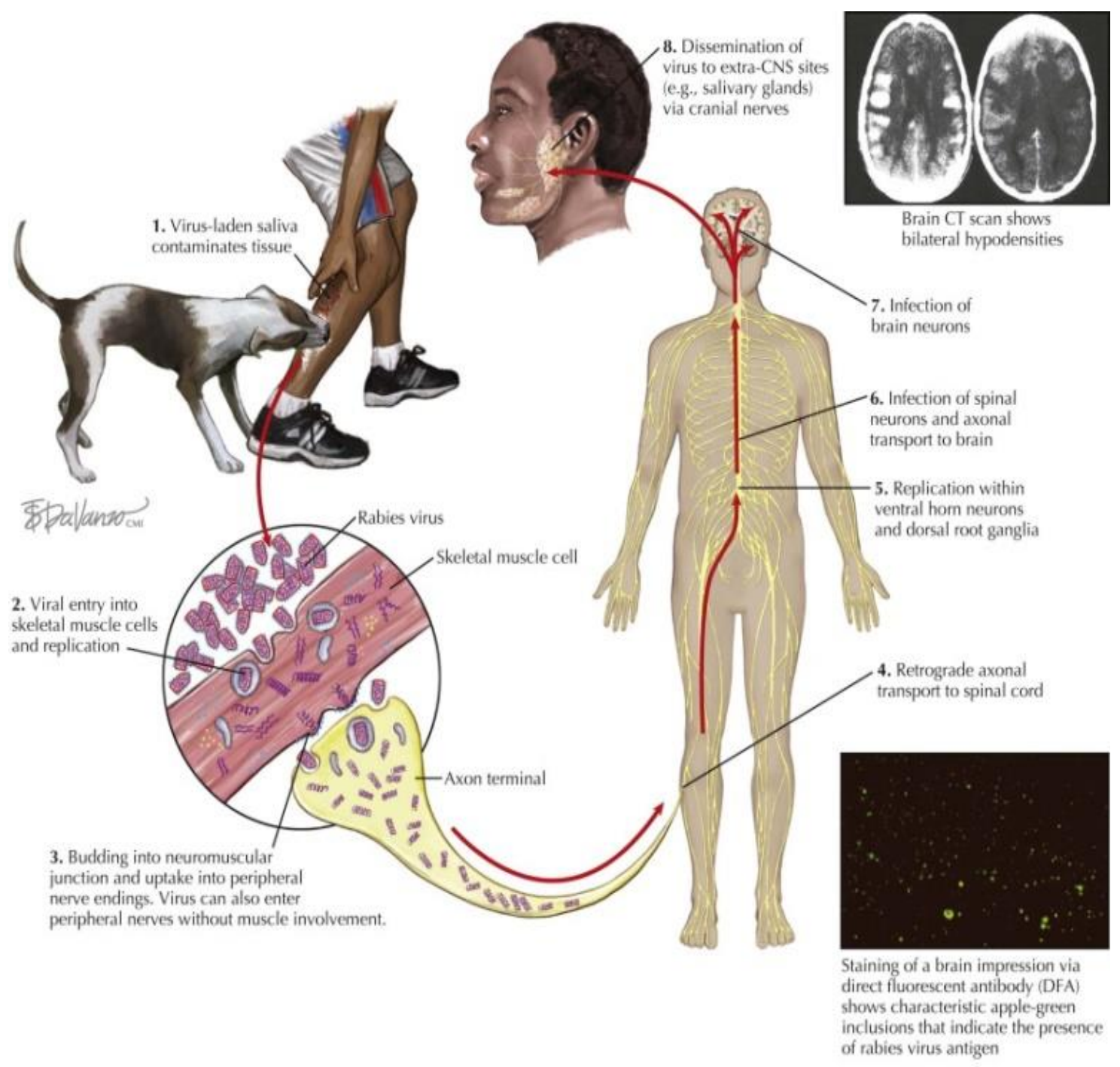

Figure 1. Pathophysiology of Rabies. ${ }^{2}$

Table 3. Infectious pathogens in dog bite wounds. ${ }^{1}$

\begin{tabular}{ll}
\hline \multicolumn{1}{c}{ Types of bacteria } & Dog bite \\
\hline Aerob & Pasteurella spp. \\
& Pasteurella multocida \\
& Streptococcus spp. \\
& Staphylococcus spp. (incl. MRSA) \\
& Neisseria spp. \\
& Capnocytophaga canimorsus \\
\hline Anaerob & Fusobacterium spp. \\
& Bacteroides spp. \\
& Porphyromonas spp. \\
& Prevotella spp. \\
\hline
\end{tabular}


Table 4. Animal bites with a high risk of infection. ${ }^{1}$

Wound nature

- Deep wounds

- Contaminated wounds

- Wounds with tissue damage characterized by edema and poor perfusion

- Wounds at hands, feet, face, and genitals

- Wounds with suspected joint involvement

- Bite wounds near prosthetic joint implant
Patient characteristics

Animal species

- Impaired immune response

- Cat (immune deficiency, chronic liver disease, asplenism, age of $<2$ years, and diabetes mellitus)

- Pre-existing vein or lymphatic stasis in the area of wounds

- Prosthetic heart valves

Table 5. Infectious pathogen in animal bite wounds. ${ }^{1}$

\begin{tabular}{ll}
\hline \multicolumn{1}{c}{ Types of bacteria } & \multicolumn{1}{c}{ Cat bite } \\
\hline Aerob & Pasteurella spp. \\
& Streptococcus spp. \\
& Staphylococcus spp. (incl. MRSA) \\
& Moraxella spp. \\
& Bartonella henselae \\
\hline Anaerob & Fusobacterium spp. \\
& Bacteroides spp. \\
& Porphyromonas spp. \\
& Veillonella \\
\hline
\end{tabular}

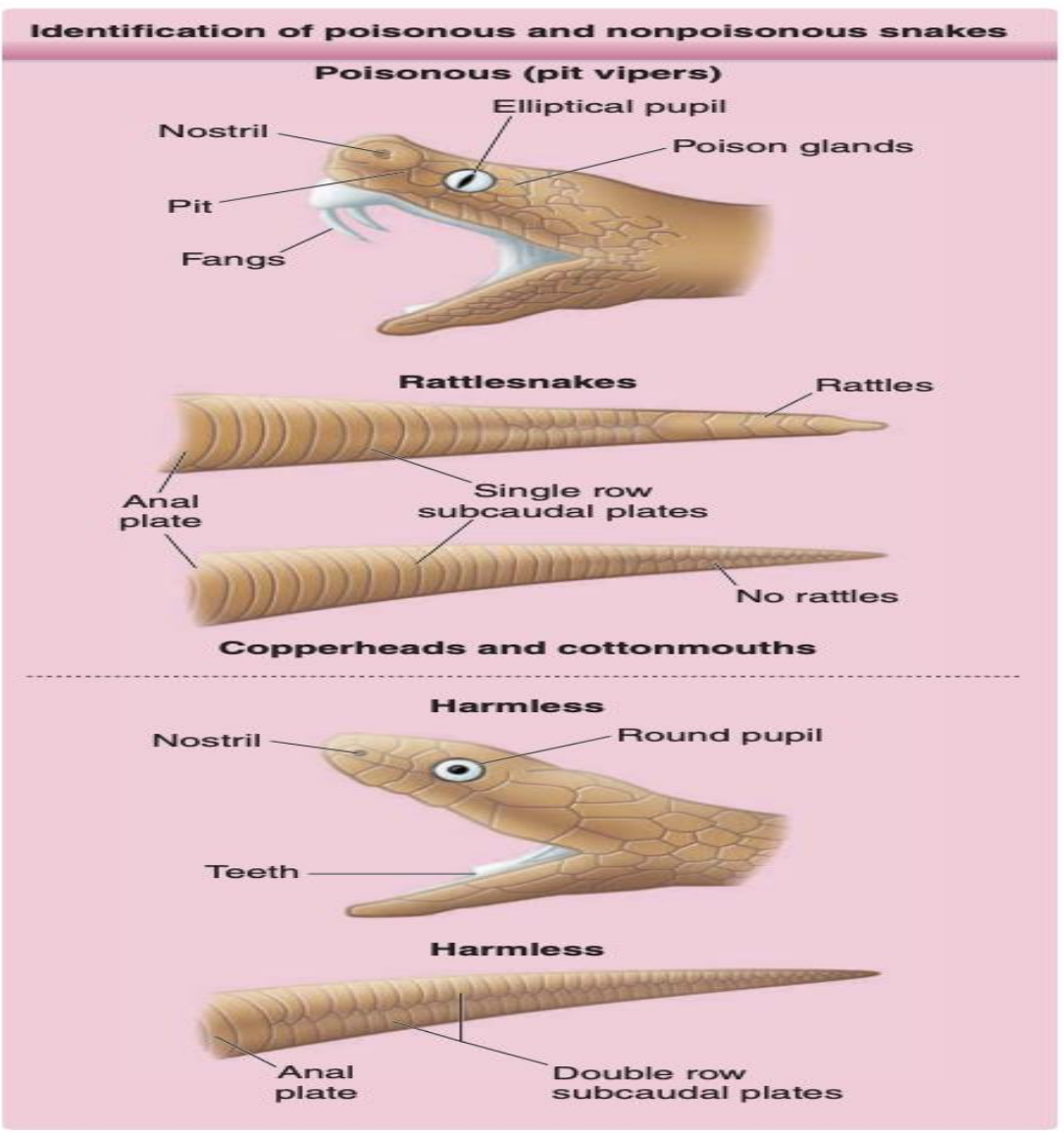

Figure 2. The difference between venomous and non-venomous snakes. ${ }^{11}$ 
In the case of venom poisoning, identifying a type of snake and clinical manifestations of envenomation (Figure 2) is required. Venomous snakebites should be differentiated from non-venomous ones during the assessment. $^{11}$

Snake venom consists of several enzymes, such as protease, phospholipase A2 (P1A2), and bradykininreleasing-enzyme. Local pain and swelling are the main symptoms of snakebite; subcutaneous bleeding and blisters are sometimes observed. The swelling and pain spread gradually from the bite site. Most snakebites occurred in hand or foot. However, the swelling frequently spread to the trunk. ${ }^{9}$ The envenomation of snakebites in humans has many potential effects. However, only a few categories have a significant major symptom, which are flaccid paralysis, systemic myolysis, coagulopathy and hemorrhage, damage and kidney disorders, cardiotoxicity, and local tissue damage in the bite area. ${ }^{8}$

\section{DISCUSSION}

According to the consensus, the clinical risk of infection due to animal bites can be divided into two groups, the low risk, and high-risk group. It depends on the cause, nature, and location of injuries and characteristics of the patient. Early medical care important for future functional and aesthetic outcomes. $^{9}$

Standard management for dog wounds are gram staining and culture, wash and irrigate the wound, let the wound opened is ideally, Amoxicillin/Clavulanic acid or Ceftriaxone for 70-10 days, or Quinolone, Tetracycline for the allergic patients, intravenous antibiotics and surgery if required, evaluation of tetanus immune status, and antirabies vaccine. ${ }^{11}$

Antibiotics must be administered for 3-5 days for new, deep, and injured wounds at certain areas (hands, feet, joint injuries, facial, and genitalia). Patients with high-risk infection and with implants (prosthetic heart valves). Prophylactic antibiotic administration is not required in bites that occur longer than 24 hours and present without infection. ${ }^{12}$

Amoxicillin/Clavulanic acid is the current recommended antibiotic for treating cat bites, and 75\% of patients received Amoxicillin/Clavulanic acid as the main antibiotic therapy. Pasteurella sensitivity is not susceptible to many other antibiotics administered routinely for skin and soft tissue infections such as Flucloxacillin or Erythromycin. Use of prophylactic antibiotics for small or superficial wounds following cat bite showed effective in reducing the rate of infection from $28 \%$ to $2 \%$. Only five cases $(25 \%)$ had preceding antibiotic treatment or prophylaxis before their referral. The first line prophylactic antibiotics for the cate bite is Amoxicillin/Clavulanic acid 875/125 mg every 12 hours. $^{13,6}$

In the United States, there are 5-6 deaths due to snakebites and around 6,000-7,000 cases of venomous snakebites annually. The largest number of venomous snakebites occurred in the Southwestern states. ${ }^{14}$ Globally, there are 125,000 fatal snakebites each year. There is no adequate data on the epidemiology of snakebite in Southeast Asia, and there is no definitive data of snakebite cases in Indonesia either WHO estimates 421,000 snakebite cases, with 20,000 deaths occurring in South Asia. ${ }^{4,15}$

The aids for venomous snakebites are patients should be stabilized and transferred to the health care facility that provides antivenom as soon as possible, the affected part of the bite should be immobilized, lower than the heart, the straps such as watches and jewelry should be removed, and the patients should be immobilized as long as possible, the use of vein compression binders or pressure immobilization is still controversial. However, this technique may be beneficial in cases with delayed transport, and the victims present with systemic symptoms of poisoning such as hypotension, the benefit of suction tools to remove toxins is still debatable, use of cryotherapy, incision, or excision of the bite area, arterial tourniquet, and electroshock therapy as part of emergency therapy should be avoided. ${ }^{10}$

Terrestrial animal bite wound is an injury caused by the mouth and teeth of terrestrial animals. A broad spectrum of wounds and complications can occur. All animal bite wounds and crush injuries are at risk of infection. Many complications can be prevented with proper diagnosis as well as quick and precise handling. The accuracy of first aid and comprehensive management of each bite case are necessary to reduce morbidity and mortality.

\section{REFERENCES}

1. Rothe K, Tsokos M, Handrick W. Animal and human bite wounds. Dtsch Arztebl Int 2015; 112(2): 433-43.

2. Robertson K, Marano N, Johnson KJ. Rabies. In: Jong EC, Stevens DL, editors. Netter's Infectious Disease. Philadephia: Elsevier Inc. 2012. p.6875.

3. Departemen Kesehatan RI. Buku Saku Petunjuk Perencanaan dan Penatalaksanaan Kasus Gigitan Hewan Tersangka/Rabies di Indonesia. Jakarta: Departemen Kesehatan RI Direktorat Jendral PPM \& PL. 2016. p.26-40.

4. World Health Organization. Guidelines for the management of snakebites. India: WHO. 2016. Pp. 230-55. 
5. Giordano A, Dincman T, Clyburn BE, Steed LL, Rockey DC. Clinical features and outcomes of Pasteurella multocida infection. Medicine 2015; 94(36): e1285.

6. Ellis R, Ellis C. Dog and cat bites. American Family Physician 2014; 90(4): 239-43.

7. Zhu S, Guo C. Rabies control and treatment: from prophylaxis to strategies with curative potential. MDPI 2016; 1(1): 1-23.

8. Alkaabi JM, Neyadi MA, Darei FA, Mazrooei MA, Yazedi JA, Abdulle AM. Terrestrial snakebites in the South East of the Arabian Peninsula: patient characteristics, clinical presentations, and management. PLoS One 2011; 6(9): 9-14.

9. Hifumi T, Sakai A, Kondo Y, Yamamoto A, Morine N, Ato M, Keigo S, Umezawa K, Kiriu N, Kato H, Koido Y, Inoue J, Kawakita K, Kuroda $\mathrm{Y}$. Venomous snake bites: clinical diagnosis and treatment. Journal of Intensive Care 2015; 3(1): 2-9.

10. Pfortmueller CA, Efeoglou A, Furrer H, Exadaktylos AK. Dog bite injuries: primary and secondary emergency department presentations: a retrospective cohort study. Scientific World
Journal 2013; 1(1): 65-70.

11. Janniger CK, Schwartz RA, Daly JS, Scharf MJ. Bites and stings of terrestrial and aquatic life. In: Kang S, Amagai M, Brucker AL, Enk AH, Margolis DJ, McMichael AJ, et al., editors. Fitzpatrick's Dermatology $9^{\text {th }}$ Edition. New York: McGraw-Hill Company. 2019. p.3338-44.

12. Lee JK, You Y, Kim WY, Lee CD, Koh HS, Kim SJ, Roh YS, Hong KM. Domestic dog and cat bites: epidemiology and analysis of 823 cases over the last 5 years. Korean Wound Management Society 2019; 15(2): 68-77.

13. Kheiran A, Palial V, Rollett R, Wildin CJ, Chatterji U, Singh HP. Cat bite: an injury not to underestimate. Journal of Plastic Surgery and Hand Surgery 2019; 1(1): 1-6.

14. Bhaumik S, Beri D, Lassi ZS, Jagnoor J. Interventions for the management of snakebite envenoming: an overview of systematic reviews. PLOS Neglected Tropical Diseases 2020; 14(10): 1-26.

15. Edgerton MT, Koepplinger ME. Management of snakebites in the upper extremity. The Journal of Hand Surgery 2018; 1(1): 1-6. 